PUBLIPRENEUR POLIMEDIA: JURNAL ILMIAH

POLITEKNIK NEGERI MEDIA KREATIF

Vol.5, No. 2, December 2017

Submitted: 12 October 2017

Revised: 13 November 2017

Accepted: 30 December 2017

\title{
PERANCANGAN DESAIN BOOTH 3D UNTUK PRODUK DANCOW DI CV. XPRO ORGANIZER
}

\author{
Politeknik Negeri Media Kreatif \\ Salam Irianto Nadeak ${ }^{1}$, Dedi Buana ${ }^{2}$ \\ salamirianto66@gmail.com
}

\begin{abstract}
Abstrak
Kini booth sudah berkembang sangat pesat. Dengan perkembangan teknologi yang semakin canggih dapat memudahkan orang-orang kreatif dan memiliki ilmu pengetahuan di bidang tiga dimensi (3D) untuk menghasilkan sebuah karya, khusus nya dalam pembuatan booth. Keberadaan booth sudah banyak digunakan dalam mempromosikan produk maupun jasa, keperluan event dan lain-lain. Booth menjadi media promosi yang cukup sukses untuk menarik perhatian konsumen. Fungsi booth yaitu sebagai ajang promosi dan pembangun imeg perusahaan dan membangun korespondensi yang lebih dekat dengan pihak yang menjadi target pengguna. Perancangan adalah kemampuan untuk membuat beberapa alternatif pemecahan masalah. Dengan demikian diharapkan perancangan adalah kemampuan untuk membuat beberapa alternatif pemecahan masalah. Perancangan desain booth tiga dimensi (3D) yang bertujuan sebagai media promosi produk dancow. Perancangan Desain booth dancow menggunakan konsep desain yang sederhana. Dimana konsep tersebut mengandalkan material yang mudah dibuat dan diperoleh. Proses Perancangan Desain Booth 3D untuk produk Dancow di perusahaan Xpro Organizer di awali dengan riset. Kemudian dilanjutkan dengan pembuatan konsep yang sesuai dengan kebutuhan perusahaan dalam menghadapi pesaingnya yang diwujudkan dalam bentuk visualisasi tiga dimensi (3D) terhadap desain yang dihasilkan. Proses perancangan visual tiga dimensi (3D) menggunakan software autodesk 3Ds Max 2010 dan plugin Vray 2.2 dan produk akhir dari perancangan desain booth berupa visualisasi tiga dimensi (3D) dalam bentuk media cetak dan mini booth.
\end{abstract}

\section{Kata Kunci: Perancangan, Desain Booth, CV. Xpro Organizer}

\section{PENDAHULUAN}

Semakin kompleks dan pesatnya perkembangan ilmu pengetahuan dan teknologi memberikan pengaruh positif dalam bidang usaha, sehingga mendorong para pengusaha untuk menghasilkan produk dalam jumlah yang besar dengan jenis produk yang bervariasi serta kualitas memadai. Para pelaku bisnis di industri terus berupaya agar apa yang mereka hasilkan dan tawarkan diinginkan dan diminati oleh konsumen sehingga mampu menjual produk 
dengan tingkat penjualan yang maksimal.

Oleh karna itu pengusaha dituntut untuk mampu dalam memilih strategi pemasaran yang akan digunakan. Dalam memasarkan produk harus menggunakan strategi pemasaran yang tepat khususnya dalam bidang promosi. Karena tujuannya adalah menarik perhatian masyarakat agar dapat mendongkrak penjualan produk, maka aktivitas promosi haruslah dilakukan dengan cara kreatif. Aktivitas promosi tentu akan lebih diminati apabila dilakukan dengan cara yang berbeda dan unik. Di luar itu, banyak sekali cara untuk melakukan promosi, baik secara langsung ataupun melalui suatu media perantara.

Beberapa media perantara yang dapat digunakan sebagai sarana untuk mempromosikan produk bisnis antara lain adalah media elektronik ataupun media cetak. Dengan perkembangan teknologi yang semakin canggih, maka media perantara yang di gunakan untuk promosi tidak bergantung kepada media elektronik maupun media cetak. Melainkan sekarang telah hadir inovasi baru yaitu promosi menggunakan booth.

Booth merupakan sebuah mini stage beserta aksesorisnya yang digunakan sebagai ajang promo produk, jasa, maupun branding perusahaan pada sebuah event pameran/exhibition. Booth biasanya dibuat untuk sekali atau $2 x$ event yang sifatnya musiman. Model maupun bentuk dari booth itu sendiri biasanya menyesuaikan identitas perusahaan, serta desain pameran/event haruslah memenuhi dua tujuan yaitu :
1. Membangun imeg (branding) perusahaan dan menjual produk/jasa

2. Memanfaatkan semua aspek desain untuk berkomunikasi dan mengkontrol suasana yang terbangun juga termasuk sebagai tujuan.

Beberapa tahun ke belakang booth mengalami perkembangan yang sangat signifikan dikarenakan banyak perusahaan yang menggunakan booth sebagai media untuk mempromosikan produk maupun jasa yang mereka tawarkan. Adanya booth mampu menjadi daya tarik tersendiri di mata konsumen. Booth menjadi pembeda di antara banyaknya stand - stand di luar sana, sehingga mudah untuk di ingat.

Pada era modern sekarang ini booth menjadi media promosi yang cukup sukses untuk menarik perhatian konsumen, dengan desain yang cukup menarik dan skala size yang tidak terlalu besar sehingga booth mampu di letakkan di tempat tempat ramai seperti mall. Adapun fungsi booth yaitu :

1. Sebagai ajang promosi dan pembangun imeg perusahaan 
2. Membangun korespondensi yang lebih dekat dengan pihak yang menjadi target pengguna

Pada saat ini booth sudah berkembang sangat pesat. Dengan perkembangan teknologi yang semakin canggih dapat memudahkan orang-orang kreatif dan memiliki ilmu pengetahuan di bidang tiga dimensi (3D) untuk menghasilkan sebuah karya, khusus nya dalam pembuatan booth.

Keberadaan booth sudah banyak digunakan dalam mempromosikan produk maupun jasa, keperluan event dan lain-lain. Booth menjadi media promosi yang cukup sukses untuk menarik perhatian konsumen, dengan desain yang cukup menarik dan skala size yang tidak terlalu besar sehingga booth mampu di letakkan di tempattempat ramai seperti mall.

Selama ini booth hanya sekedar wadah display suatu produk sehingga terkesan monoton, tetapi sekarang ini sudah terjadi perubahan trend bahwa booth bukan hanya sebagai display semata. Kini booth menjadi media promosi yang cukup sukses, untuk itu penulis ingin membuat penelitian dengan judul Perancangan desain booth 3D untuk produk Dancow di CV. XPro Organizer.

\section{TUJUAN}

Adapun tujuan dari penulis antara lain :
1. Untuk mengetahui konsep booth produk dancow pada CV. XPro Organizer.

2. Untuk mengetahui proses perancangan booth produk dancow pada CV. XPro Organizer menggunakan aplikasi 3ds Max.

3. Untuk mengetahui hasil visual rancangan desain booth tiga dimensi (3D) produk dancow pada CV. XPro Organizer.

\section{METODE PENELITIAN}

Penulisan penelitian ini berdasarkan beberapa metode yang telah tersusun rapi dari awal pengumpulan data hingga menjadi sebuah perancangan yang hasil akhirnya akan menjadi bentuk nyata sesuai dengan spesifikasi proyek yang dikerjakan, yaitu :

\section{a. Observation ( penelitian)}

Penulis melakukan penelitian dan pengamatan mengenai booth yang akan di buat, dengan cara melihat referensi booth di internet dan buku. Sehingga penulis mampu mendapatkan gambaran bagaimana booth yang akan dibuat nantinya.

\section{b. Wawancara}

Penulis mengadakan wawancara dan diskusi dengan pihak yang bersangkutan, terutama kepada klien pemilik CV. XPro Organizer agar memperoleh penjelasan lebih rinci tentang booth yang akan di buat, 
sehingga Booth dapat di buat sesuai dengan keinginan klien.

\section{c. Kepustakaan}

Penulis mencari berbagai sumber bacaan yang digunakan penulis untuk mencari dan mengumpulkan data-data yang diperlukan dari berbagai referensi seperti buku, internet, software desain grafis dan makalah yang berkaitan dengan topik yang diangkat penulis.

\section{HASIL DAN PEMBAHASAN}

Analisa visual produk Dancow Advanced Excelnutri+ adalah susu pertumbuhan anak usia 1-15 tahun yang merupakan inovasi terbaru dari Nestle Research Centre. Dengan kandungan lebih dari tiga kali Lactobacillus rhamnosus dibandingkan produk sebelumnya. Perlindungan sebagai pondasi untuk mendukung pertumbuhan fisik dan perkembangan otak si Kecil.

\section{a. Perlindungan}

Tiga perlindungan untuk mendukung perlindungan Saluran Pernafasan, Daya Tahan Tubuh dan Saluran Cerna :

1. Bakteri baik Lactobacillus rhamnosus

2. Serat Pangan Inulin

3. Tinggi Vitamin A, C, E, D, Fe, Selenium, \& Zink

\section{b. Proses Belajar}

1. Minyak Ikan untuk membantu perkembangan otak dan retina

2. Omega tiga \& enam sebagai asam lemak esensial dan prekusor DHA dan AA.

\section{c. Pertumbuhan Fisik}

Protein sebagai komponen esensial untuk pertumbuhan $\&$ perkembangan anak Kalsium untuk membangun dan mempertahankan kepadatan tulang dan gigi.

\section{Konsep Desain Booth}

Memasuki tahapan selanjutnya adalah proses pengonsepan atau pengumpulan ide. Penulis memilih perancangan desain booth yang sederhana. Jadi desain booth produk dancow yang saya desain ini berukuran lima meter $x$ tiga meter, dimana bentuk booth ini menampilkan bentuk yang sederhana, dengan ilustrasi gambar sesuai dengan tema dancow yaitu Kidtropolis, lalu ada lingkaran di atas booth saya angkat dari kaleng dancow, serta di dalamnya terdapat meja registrasi, rak display, laptop, Tv dan aksesoris lainnya. Serta yang menarik di dalam booth ini terdapat beberapa Games yang mampu mengasah kemampuan berfikir si anak, di antaranya yaitu games menyusun puzzle, lomba mewarnai, dan fotowall. Games sengaja di adakan 
sebagai penarik perhatian konsumen. Untuk bisa bermain, konsumen harus membeli produk dancow terlebih dahulu.

\section{Skala Perbandingan}

Skala adalah perbandingan antara satu bentuk atau ruang dengan bentuk dan ruang tertentu dengan ukurannya bagi manusia. Disini penulis membuat miniature booth dengan skala $1: 12.5 \mathrm{~cm}$.

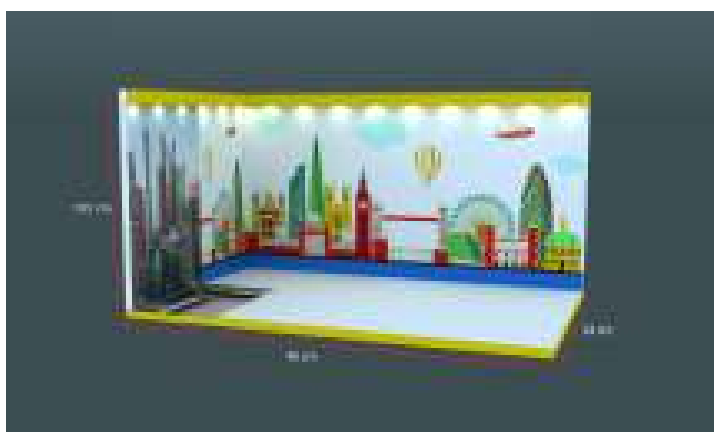

Gambar 1 Dinding booth skala 1 : $12.5 \mathrm{~cm}$

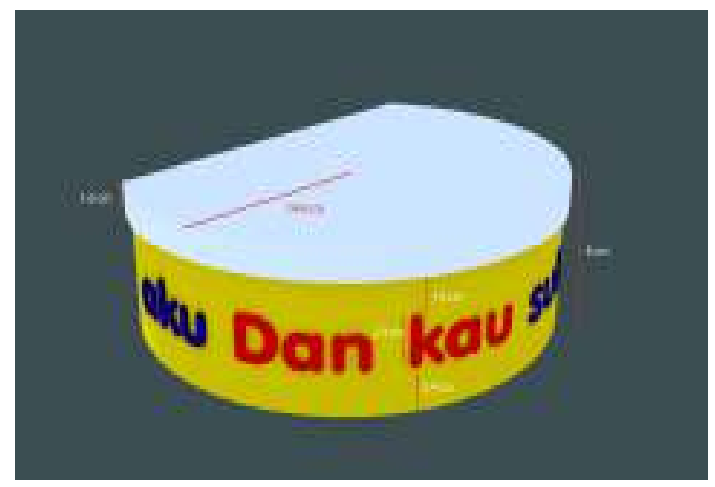

Gambar 2 Lingkaran atas skala 1 : $12.5 \mathrm{~cm}$

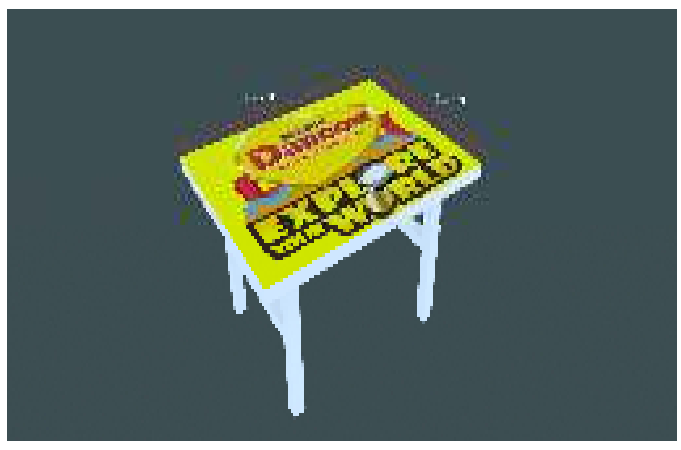

Gambar 3 Meja mewarnai skala 1 : $12.5 \mathrm{~cm}$

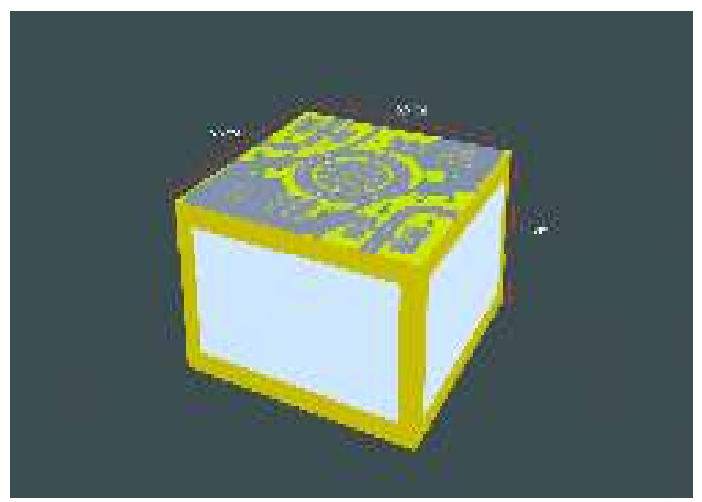

Gambar 4 Meja puzzle skala $1: 12.5$ $\mathrm{cm}$

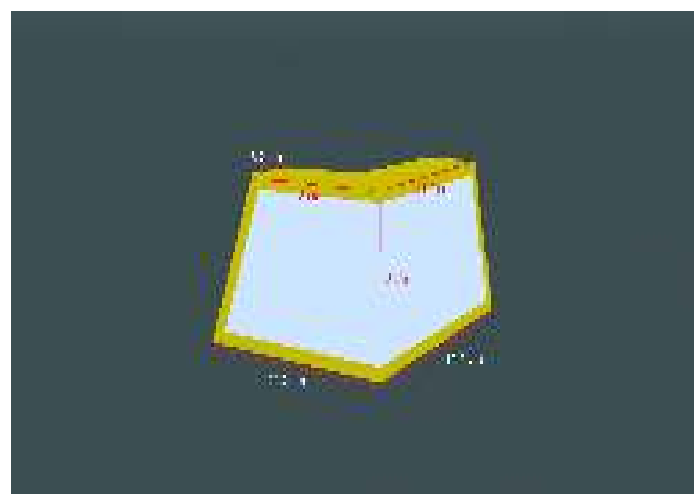

Gambar 5 Meja registrasi skala $1: 12.5$ $\mathrm{cm}$ 


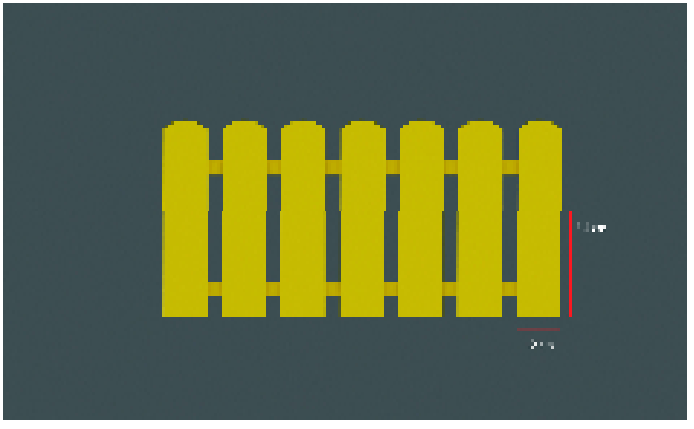

Gambar 6 Pagar skala $1: 12.5 \mathrm{~cm}$

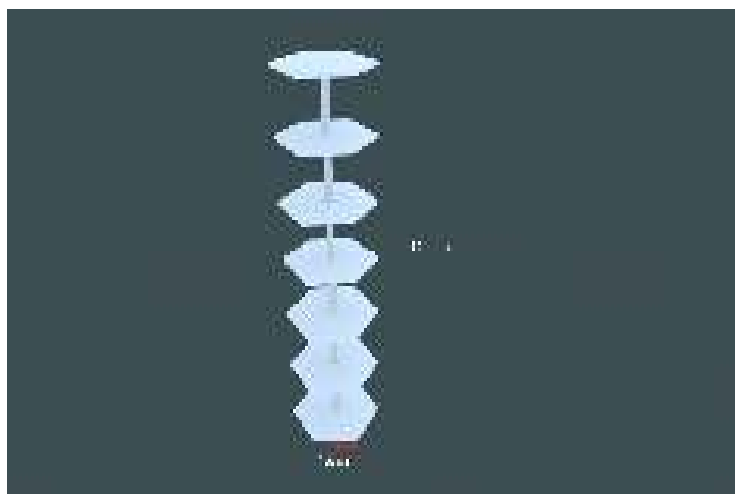

Gambar 7 display produk skala 1 : $12.5 \mathrm{~cm}$

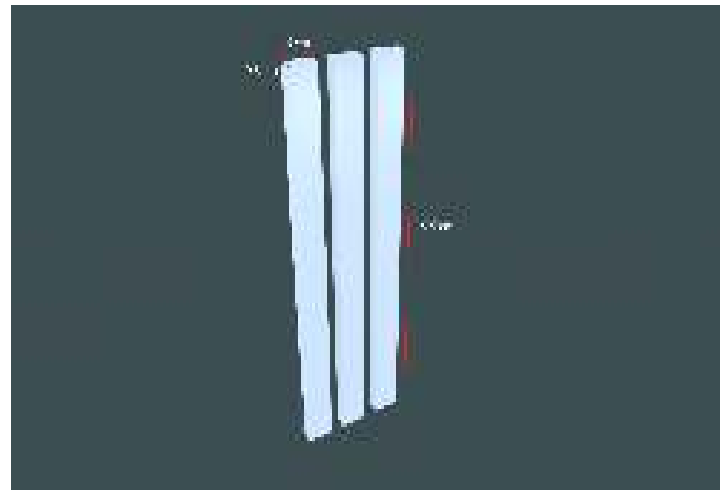

Gambar 8 Tiang penyanggah skala $1: 12.5 \mathrm{~cm}$

\section{Proses Desain Booth Dancow}

Tahapan awal dalam proses desain booth Dancow adalah membuat suatu layout kasar atau sketsa dengan menggunakan gambar di kertas. Kemudian proses desain material booth menggunakan software Autodesk 3ds Max 2010. Desain material yang dibuat berupa kursi, lampu, meja, pagar dan sebagainya. Setelah desain material selesai, maka tahapan selanjutnya adalah proses penggabungan material sehingga membuat suatu konsep desain booth yang telah dirancang.

\section{Perancangan Sketsa Desain}

Berlanjut pada tahap selanjutnya adalah sketsa, dalam dunia seni, baik itu seni murni maupun terapan, sketsa adalah salah satu bagian penting dalam menciptakan suatu karya. Peranan sketsa adalah bagian awal dari perancangan, yang berupa goresan yang dibuat untuk memulai penerapan ide.

\section{Aplikasi yang digunakan}

Telah disebutkan bahwa dalam membuat desain tersebut, digunakan aplikasi komputer. Di sini akan di 
tuntut untuk dapat membuat desain tersebut menggunakan komputer grafis dengan software atau aplikasi tiga dimensi (3D). Dalam pembuatan tugas ahir ini penulis menggunakan software 3ds Max dan Plugin Vray.

\section{a. Software 3ds Max}

Aplikasi 3ds Max merupakan aplikasi yang berbasis tiga dimensi (3D) yang dilengkapi dengan fiturfitur dan tool pembuatan modeling yang cukup populer dan banyak digunakan saat ini. Kemampuan dan cara pengoprasiannya sangat mudah bagi para penggunanya.

Aplikasi Autodesk 3ds Max 2010, merupakan program aplikasi desain grafis yang memadukan antara graphic vector dan raster image sehingga objek yang dihasilkan begitu detail.

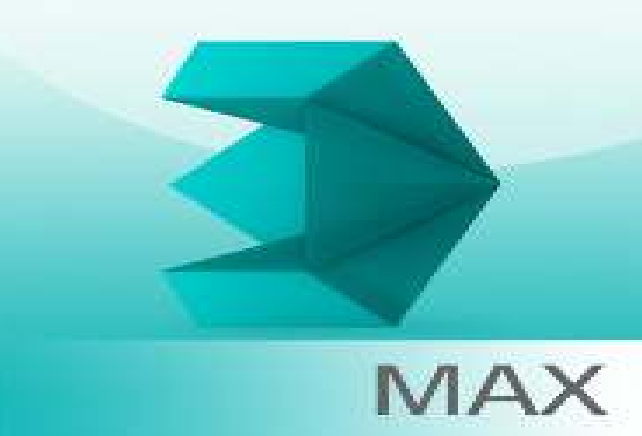

Gambar 9 Software Plugin 3ds $\operatorname{Max}$

\section{b. Plugin Vray}

Vray adalah plugin dari

3ds Max yang berperan dalam memperindah pencahayaan dan penampilan (rendering) dari objek-objek 3ds Max. Sementara plugin adalah software atau aplikasi tambahan yang mendukung software utamanya yang dalam hal ini adalah 3ds Max. Jadi, Vray merupakan software bantu yang mendukung performa software.

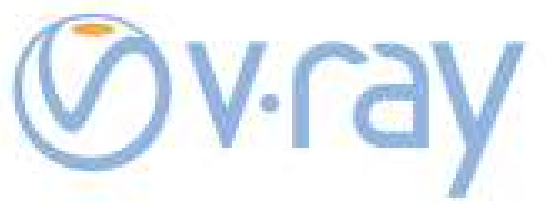

Vray

Vray merupakan salah satu plugin yang paling popular di gunakan oleh para desainer. Hal ini di sebabkan vray memiliki beberapa keunggulan, di antaranya sebagai berikut :

1. Vray memiliki setingan parameter yang mudah dan tidak merepotkan pengguna (desainer).

2. Vray memiliki kalkulasi waktu render yang lebih cepat di bandingkan dengan plugin render sejenisnya.

3. Vray mudah didapatkan (Aditya, 2012:11) .

\section{Visualisasi Tiga Dimensi}


Visualisasi tiga dimensi (3D) merupakan konsep desain booth yang sebenarnya dan bentuk akhir dari keseluruhan perancangan desain booth. Visualisasi tiga dimensi (3D) terdiri dari media cetak, media tiga dimensi mini booth, dan animasi.

\section{KESIMPULAN}

Kesimpulan yang di dapat oleh penulis dalam proses Perancangan Desain Booth 3D untuk produk Dancow di CV. XPro Organizer :

1. Perancangan Desain booth dancow menggunakan konsep desain yang sederhana. Dimana konsep tersebut mengandalkan material yang mudah dibuat dan diperoleh.

2. Proses Perancangan Desain Booth 3D untuk produk Dancow di CV. XPro Organizer di awali dengan riset. Kemudian dilanjutkan dengan pembuatan konsep yang sesuai dengan kebutuhan perusahaan dalam menghadapi pesaingnya yang diwujudkan dalam bentuk visualisasi tiga dimensi (3D) terhadap desain yang dihasilkan.

3. Proses perancangan visual tiga dimensi (3D) menggunakan software Autodesk 3ds Max 2010 dan plugin Vray 2.2 dan produk akhir dari perancangan desain booth berupa visualisasi tiga dimensi (3D) dalam bentuk media cetak, mini booth dan animasi.

\section{DAFTAR PUSTAKA}

Anggraini, Lia S. \& Nathalia, K. 2016. Desain Komunikasi Visual Dasar-Dasar Panduan Untuk Pemula. Bandung: Nuansa Cendikia

Max. 2010. Semarang: Smitdav Community

Muklis, Muhammad. 2015. “ Laporan Tugas Akhir Dengan Judul Perancangan Desain Interior Café Ikhwan “ Medan.

Rustan, Surianto. 2008. “Layout Daasar Dan Penerapannya". Jakarta: Gramedia Pustaka Utama

S.T, Aditya. 2012. "Panduan Mudah Membuat Visualisasi 3D Arsitektural", Jakarta: Griya Kreasi (Penebar Swadaya Group)

Safitri, Ayu Widya. 2013. LKP : Pembuatan Layout Pada Program Administrasi Pembukuan PT.

Soedarso, Nick. 2014. Perancangan Buku Ilustrasi Mahapatih Gajah

Mada. Humaniora. Vol. 5, No. 2, Oktober 2014, 561-570 
Sugianto, Mikael, 2010. "Mudah Dan Cepat Merancang Dengan 3ds

Suwarno, Wiji. 2011. Perpustakaan buku: wacana penulisan \& penerbitan. Jogjakarta: Ar-Ruzz Media
Wibowo, Ibnu Teguh, 2015. "Belajar Desain Grafis", Yogyakarta: Notebook. 